\title{
THEORETICAL AND EMPIRICAL RESEARCH ON THE ANALYSIS AND THE ASSESSMENT OF THE STABILITY OF NATIONAL FINANCIAL SYSTEMS. ROMANIA'S EXPERIENCE
}

\author{
Leontin STANCIU*, Liliana-Mioara STANCIU** \\ *"Nicolae Bălcescu" Land Forces Academy Sibiu, \\ **SC MORU CAMIONTECHNICA SRL, Sibiu \\ leontinstanciu@yahoo.com, liliana_stanciu_ro@yahoo.com
}

\begin{abstract}
The stability of the financial systems is an objective necessity for the sustainable development of each national economy. Within this framework, ensuring financial stability is a priority for the central banks and for the other macro-prudential supervisory and regulatory authorities. In order to ensure the stability and "the health" of the national financial system, the competent authorities should analyze, assess and adopt optimal and timely measures to eliminate potential imbalances. These and other aspects are the main objectives of our research.
\end{abstract}

Keywords: national financial system, financial stability, analysis and assessment, indicators of financial stability

\section{Introduction}

A modern knowledge-based economy cannot exist without a healthy stable financial system. The problem of financial stability, the means of analyzing and assessing it, have concerned over time more and more specialists. In recent years, ensuring financial stability and price stability have been among the main concerns of the central banks which are the core of the national financial systems. In this context, the analysis and the assessment of the financial stability require effective and continuous cooperation, at national and international level, between the various supervisory and regulatory authorities. Periodically, a number of central banks, including the National Bank of Romania, issue reports on financial stability. These are drawn up according to regulations and methodologies that use specific financial stability indicators. These particularities, as well as others, are the main objectives of our research.
1. The Stability of the Financial System -A Prerequisite and a Consequence of a Sustainable Economic Development

In the functional market economy, the financial system has a determinative role. Its stability ensures capital accumulation, facilitates a better risk distribution, guarantees the financing of all investment opportunities, and ultimately makes a decisive contribution to achieving sustainable economic development.

At national level, the financial system consists of the following components:

- the financial markets (namely, the money market and the capital market)

- the financial infrastructure (providing the transfer of payments, the trading, the settlement and the clearing of securities value)

- the financial intermediaries (indirectly facilitates the connection between creditors and debtors). 
At international level, unlike price stability, there is no comprehensive definition that highlights the vast range of financial stability, both at a conceptual and an empirical level. At the same time, there is no consensus concerning the role of the central banks in ensuring the stability of the financial system, even if their preoccupation for supporting it has become a reality for a long time. [1]

By studying a series of researches in the literature, we have identified two fundamental concepts associated to this financial concept, as follows:

- the absence of general episodes of vulnerability which would affect the efficient functioning of the national financial system;

- the resilience of the national

financial system to endogenous and/or exogenous adverse shocks.

Also, there are specialists who define the stability of the financial system by reference to its reverse, namely to the state of financial instability. [2]

Andrew Crockett believes that the stability of the financial system reflects "the situation where the economic performance is not potentially affected by the fluctuation of asset prices or by the inability of the institutions to fulfill their obligations." [3]

According to Schinasi G., financial stability is the state of the national financial system when it can simultaneously fulfill the following main functions:

- the efficient, dynamic and smooth mediation of financial resources (transfer of funds from those who own them to those who use them);

- anticipating, evaluating and rigorously managing the risks involved in

this process;

- the absorption of shocks that the real and financial economy supports and/or generates. [4]

The Bundesbank argues that the financial stability shows the state of equilibrium of the national financial system, which allows it to allocate resources efficiently, to diversify risks, to ensure the liquidation of debts, even in financial stress situations or in times of profound structural changes.

While the Bank of England considers that the fundamental objective of financial stability is to provide adequate resilience to the national financial system, the Bank of the Netherlands believes that "a stable financial system is capable of efficiently allocating resources and absorbing shocks, avoiding that they have a distinctive effect on the real economy or on other national financial systems."[5]

In its turn, the European Central Bank defines the stability of a national financial system more broadly, considering that it is a basic prerequisite of the financial system in order to be able to absorb financial shocks, to mitigate the disruptions of the financial intermediation process that may affect the decisions to allocate the savings to the investment opportunities. [6]

The National Bank of Romania, in its first Financial Stability Report, defines financial stability in a broad sense as "that feature of the financial system able to deal with systemic shocks on a sustainable basis and without major disruptions, to efficiently allocate financial resources in the economy and to identify and manage risks efficiently."[7]

Taking into account this diversity of opinions on defining the concept of national financial system, we consider that it is stable when it simultaneously fulfills two fundamental requirements, namely:

1. It actively contributes to increasing the performance of the national economy;

2. It eliminates the imbalances caused by endogenous factors or by adverse and unanticipated events.

We also believe that the involvement of the central bank in providing the stability of the national financial systems is an objective necessity, achievable through the efficient exercise of certain statutory functions, such as:

- the regulation and the supervision of the banking sector;

- the management and the monitoring of the payment systems;

- the guarantee of the bank deposits;

- the lender of last resort, etc. 
In this context, there are specialists who claim that the central bank has to deal first with securing the stability of the national financial system and then with developing and implementing the monetary policy. [8]

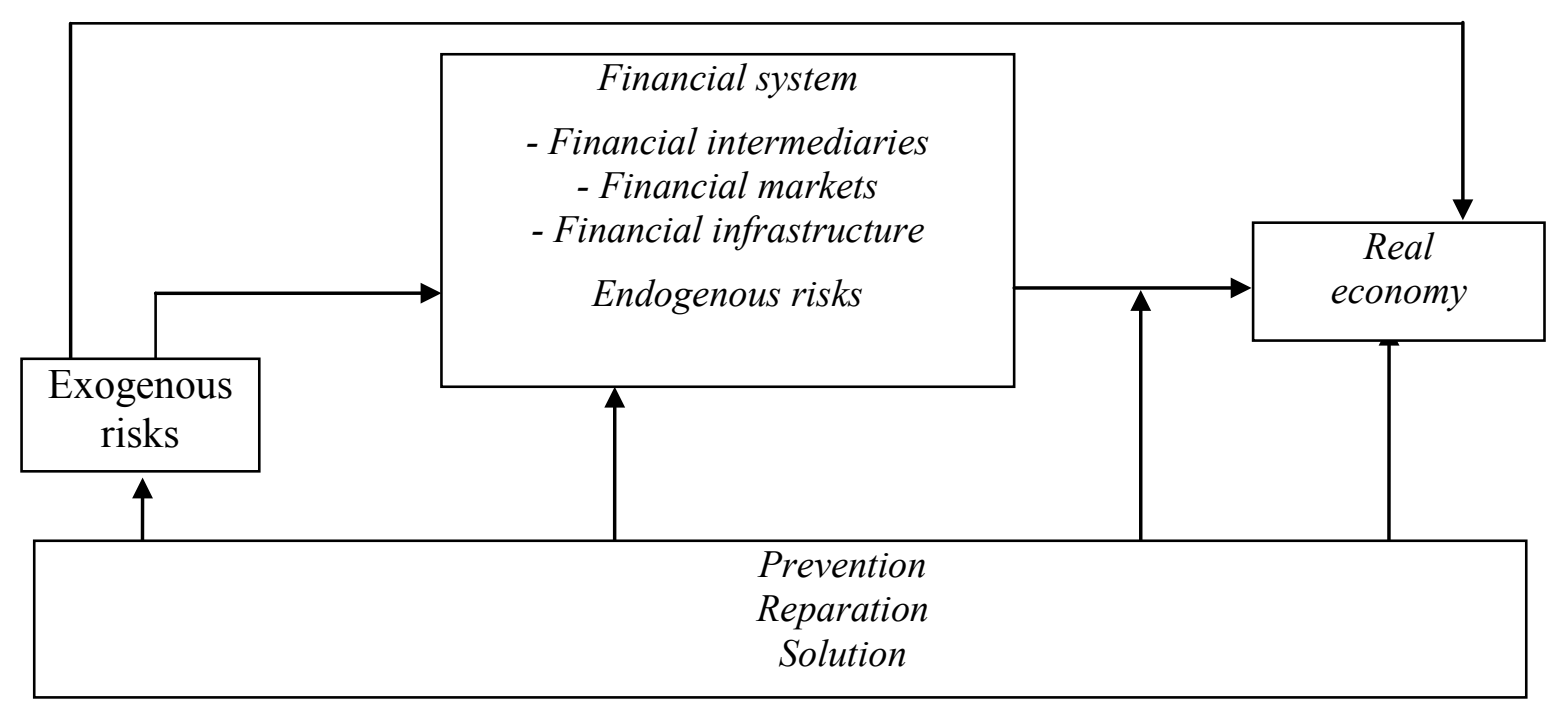

Figure no1. Framework of the Stability of a National Financial System

(Source: Schinasi. G, Defining Financial Stability, IMF Working Papers, 4, 187, 2004, p.103)

\section{Indicators Used for Analyzing and} Assessing the Stability of National Financial Systems

As can be easily observe in the figure below, the financial system is a subsystem of the national economic system, having many connections with the real economy and the economic policies promoted by the competent authorities.
Towards defining the framework of financial stability and making it operational, the starting point should be the analysis of the risks and vulnerabilities of the national financial system, the main sources of risk being presented in the table below:

Table nol. Sources of Risk for the Stability of the National Financial System

\begin{tabular}{|c|c|}
\hline $\begin{array}{l}\text { A. Risks at the level of financial institutions: } \\
\text { - financial risks (credit, liquidity, market, foreign } \\
\text { exchange, related to the interest rate); } \\
\text { - operational risk; } \\
\text { - reputational risk; } \\
\text { - risk of the business strategy; } \\
\text { - risk of the concentration of exposures; } \\
\text { - risk of capital inadequacy; }\end{array}$ & $\begin{array}{l}\text { A. Macroeconomic turbulences } \\
\text { - } \text { economic climate risk; } \\
\text { inappropriate macroeconomic } \\
\text { policies; }\end{array}$ \\
\hline $\begin{array}{l}\text { B. Risks at the level of financial markets: } \\
\text { - risk of counterparty (commercial) } \\
\text { - risk of volatility of asset prices; } \\
\text { - risk of funds withdrawal; } \\
\text { - risk of liquidity; } \\
\text { - risk of contagion; }\end{array}$ & $\begin{array}{l}\text { B. Incidental risks } \\
\text { - natural disasters; } \\
\text { - } \text { social events; } \\
\text { - bankruptcies of some economic } \\
\text { branches }\end{array}$ \\
\hline
\end{tabular}


C. Risks at the level of financial infrastructure:

- risks associated with the clearing, settlement and payment system;

- loss/deterioration of confidence in the financial system;

- fragility of the financial infrastructure (legal, audit, supervision, regulatory);

the Domino effect.

Source: Adapted after Cerna S., Donath L., Șeulean V., Herbei M., Bărgălăzan D., Albulescu C., Boldea B., "Stabilitatea financiară", Timișoara, West University Publishing House, 2008, p.20 și Houben A., Kakes J., Schinasi G., "Toward a framework for safeguarding financial stability”, IMF Working paper, wp/04/101, p.19.

The analysis of the stability of the national financial system requires the permanent monitoring of all these risks and vulnerabilities. As shown in the table above, some of these risks and vulnerabilities appear and develop within the financial system (the endogenous risks), while others outside it, in the real economy (the exogenous risks). At the same time, the analysis involves both monitoring the functionality of all the components of the financial system (institutions, markets and infrastructure) and the real economy (enterprises, public sector, population) as well as comprehensively knowing the intersectoral and cross-border economic links. The international literature, for the analysis and the assessment of the stability of a national financial system, suggests numerous systems of indicators, the most widely used in practice being:

- the system of indicators developed by the IMF (Financial Soundness Indicators);

- the tests of resilience of the financial system to the speculative stress (the stress tests);

- the early warning systems;

- other quantitative methods for analyzing and assessing the financial stability (the discriminatory analysis and the multiple discrimination). [9]

Known as "Financial Health Indicators" (FHI), the system of indicators developed by the IMF was designed to serve in conducting a macro-prudential analysis. In its turn, this analysis involves identifying, evaluating and monitoring the strengths and the weaknesses of the financial health used by the IMF for deposit-luring institutions, the following:

\section{- capital adequacy}

(Capital/Assets posing a particular risk, Capital/Assets presenting a high degree of risk);

- asset quality (non-performing loans/gross loans, non-performing loans/Capital, Sectoral distribution of loans/Total loans);

- income and profitability (Return on assets - ROA, Return on equity - ROE, Interest margin/Gross income, Expenses other than interest/Gross income);

- liquidity (Liquid assets/Total assets, Liquid assets/Total short-term liabilities)

- sensitivity to market risks (short-term open foreign exchange position);

For determining the FHI indicators, the necessary data are obtained from the balance sheet of the central bank, the consolidated balance sheet of the banking sector, the aggregate balance sheet of the non-financial corporations, the balance of payments, the stock exchange reports, the execution of the state budget. The FHI indicators can be supplemented both with indicators that highlight the situation and the evolution of the major components of the capital market (money market, stock market, government securities market, etc.) as well as a series of data reflecting the country-specific conditions (the structure of the financial system, the proportional size 
of different categories of non-banking financial institutions, etc.) [10]

Periodically, the IMF issues the "Country Reports" using the FHIs and refers to countries in Latin America, Central and Eastern Europe, Southeast Asia, etc.

\section{Romania's Experience in Analyzing and Assessing its Financial Stability}

The reality of the contemporary national economies demonstrates that a sound, healthy financial system is a determinant condition for economic growth and, implicitly, for sustainable development. Also, financial stability is a "global public good characterized by non-equity and nonexclusion" [11]

In 2010, in order to ensure the stability of the European financial system, the European Systemic Risk Board (ESRB) was established and, through Recommendation ESRB/2011/3, it called on all EU Member States to designate through their own regulation, the authority responsible for implementing the macroprudential policy. [12]

In Romania, the financial stability is provided through the joint effort of several national institutions and the coordination of the macroeconomic policies.

In order to implement the ESRB recommendations, the National Committee for Macro-prudential Supervision is established by Law no.12/2017 regarding the macro-prudential supervision of the national financial system, as an interinstitutional cooperation structure, comprising representatives of the National Bank of Romania (NBR), the Financial Supervision Authority and the Government. According to art. 2 (1) of this normative act, "the fundamental objective of this committee is to contribute to the safeguarding of the financial stability, including by strengthening the capacity of the financial system to resist shocks and by reducing the accumulation of systemic risks, thus ensuring a sustainable contribution of the financial system to the economic growth."
Within this body, RNB has a major role, being responsible, among other things, for establishing the macro-prudential policy strategy within the limits of its area of competence. Up to now, RNB:

- adopted a series of macro-prudential measures on lending to the general public and the non-financial enterprises;

- has improved its ability to monitor and manage systemic risks and vulnerabilities at the level of the financial system in Romania;

- set the following intermediate objectives of macro-prudential policy:

$\checkmark$ reducing and preventing excessive credit growth and indebtedness,

$\checkmark$ reducing and preventing excessive maturity mismatches and lack of liquidity on the market;

$\checkmark$ limiting the concentration of direct and indirect exposures;

$\checkmark$ limiting moral hazard

$\checkmark$ strengthening the resilience of the financial infrastructures. [13]

Since 2006, RNB has been published reports on the stability of the national financial system. Thus, the Financial Stability Report of December 2016, contains among others:

- the degree of financial intermediation continued its decline in 2015 and in the first half of 2016, even though the total assets in the national financial system registered a marginal increase;

- the financing is mainly targeted towards the sector of the population, lending is preponderant in national currency, and the increase of the attracted resources is done from the domestic market;

- the ratio between loans and deposits does not generate risks from a macroprudential perspective, the liquidity of the banks being consistent and sufficient to counteract the potential negative liquidity shocks;

- the quality of the bank assets improved, and the provisioning coverage is appropriate;

- the solvency indicators show appropriate values; 
- the stress tests on solvency confirm the resilience of the banking sector and the stable funding base;

- the non-banking financial sector has continued its expansion, being predominantly oriented towards the national economy, both in terms of investments and in terms of investors' profile. [14]

\section{Conclusions}

In the context of the globalization of the financial flows and of the increasingly obvious integration of the financial markets, the issue of the stability of the national financial systems has become a favorite research topic for academics and specialist institutions. The main motivation of the increased interest in this topic lies in the fact that the stable and "healthy" national financial systems have a decisive influence on the process of allocating resources and implicitly on the economic performance. Also, the special attention paid by authorities responsible for the macro-prudential supervision and regulation is also due to the fact that the stability of the national financial systems stimulates the economic development and increases the standard of living of the population.

The analytical framework for analyzing and assessing financial stability covers all the components of the national financial system. Depending on the results of the analysis, measures need to be taken in order to prevent, remedy or solve the imbalances which will ensure the functioning of the financial system within the acceptable stability limits.

The analysis and the assessment of the stability of the national financial systems require a specific methodology and tools (indicators, data sets, etc.) to allow the quantification of the vulnerabilities that could trigger financial crises. Currently, a number of indicators and techniques are used to analyze and assess the health status of the national financial systems. These are, however, limited in terms of the possibilities of modeling the economic and financial interactions and of estimating the related costs.

\section{References}

[1] Lătea. G.O, "Stabilitatea prețurilor și stabilitatea financiară în activitatea băncilor centrale", in Biblioteca economic collection, Probleme economice series, vol.425, the Economic Information and Documentation Center, p.15

[2] Boitan, I.A, "Crize bancare și sisteme de avertizare timpurie”, Bucharest, ASE Publishing House, 2011, p.77

[3] Crockett A., "The Theory and Practice of Financial Stability”, GEI Newsletter, 6, 1997, p.1-2.

[4] Schinasi G., “Defining Financial Stability”. IMF Working Papers, 4, 2004, p.82

[5] Wellink N., "Central Bank as Guardians of Financial Stability, The Seminar: Current Issues in Central Banking”, Oranjestad, 2002, p.2

[6] Lătea. G.O., op.cit, p.16

[7] NBR, "Financial Stability Report”, 2006, p.7

[8] Volcker P., "The Federal Reserve Position on Restructuring of Financial Regulation Responsabilities", Federal Reserve Bulletin, 70, 1984, p.548

[9] Cerna S.(coord), Donath L. Șeulean V., Herbei M., Bărglăzan D., Albulescu C., Boldea B., "Stabilitatea financiară" , Timișoara, West University Publishing House, 2008, p.79 and 121.

[10] Ibidem p.82

[11] Cerna S. (coord), op.cit, p.28

[12] NBR, "Financial Stability Report”, 2015, p.133

[13] NBR, op.cit, p.140-141

[14] NBR, “Financial Stability Report”, 2016, p.54-55 